\title{
The PeaMUST project: defining ideotypes for the pea crop development
}

\author{
Judith Burstin ${ }^{1, *}$, Catherine Rameau ${ }^{2}$, Virginie Bourion ${ }^{1}$ and Nadim Tayeh ${ }^{1}$ \\ 1 Agroécologie, AgroSup Dijon, INRA, Univ. Bourgogne, Univ. Bourgogne Franche-Comté, 21000 Dijon, France \\ ${ }^{2}$ Institut Jean-Pierre Bourgin, INRA, AgroParisTech, CNRS, Université Paris-Saclay, 78000 Versailles, France
}

Received 22 June 2018 - Accepted 26 September 2018

\begin{abstract}
Pea is the most widely cultivated grain legume crop in Europe. In the French research project PeaMUST, a large public and private sector partnership has been set up to undertake complementary strategies towards the development of high and stable yielding cultivars. These different strategies will contribute to the definition of a pea ideotype based on both a priori and a posteriori approaches. On the one hand, genomic selection will identify interesting genotypes which may display new phenotypic ideotypes. On the other hand, marker-assisted selection will enable cumulating resistance for a given or different stresses to reach more durably stable phenotypes. Moreover, mutations identified in candidate genes controlling aerial and root architecture will be tested for their effects on stress tolerance.
\end{abstract}

Keywords: pea / ideotype / aerial and root architecture / durable resistance / genomic selection

\begin{abstract}
Résumé - Le projet PeaMUST : définition d'idéotypes pour le développement de la culture du pois protéagineux. Le pois est la légumineuse à graines la plus cultivée en Europe. Dans le cadre du projet de recherche français PeaMUST, un vaste partenariat entre secteurs public et privé a été établi pour mettre en œuvre des stratégies complémentaires visant à développer des cultivars à rendement élevé et régulier. Ces différentes stratégies, basées sur des approches a priori et a posteriori, contribueront à la définition d'un idéotype de pois. D'une part, la sélection génomique identifiera des génotypes intéressants pouvant présenter de nouveaux idéotypes phénotypiques. D'autre part, la sélection assistée par marqueurs permettra de cumuler des résistances pour un stress donné ou pour différents stress et ainsi d'atteindre des phénotypes plus stables. Enfin, des mutations identifiées dans des gènes candidats contrôlant l'architecture aérienne et racinaire des plantes seront testées pour leur effet sur la tolérance aux stress.
\end{abstract}

Mots clés : pois / idéotype / architecture aérienne et racinaire / résistance durable / sélection génomique

The need to address global food security in the context of climate change and increasing world population has driven considerable research investment to bring innovation in agriculture including crop breeding. Climate change influences several aspects of agricultural systems including water availability, soil fertility, phenology, biodiversity, pest pressure and plant-pollinator interactions. To tackle these challenges, large French national projects have been launched a few years ago. Among these projects, the PeaMUST project searches solutions to legume crop development in France and in Europe. Legume crops provide a range of ecological services in cropping systems and produce seeds of high nutritional value for feed and food. Thanks to their symbiotic association with soil rhizobia that fix atmospheric nitrogen, the re-deployment of grain legume

*Correspondence: judith.burstin@inra.fr crops in EU could help meeting several major challenges: (i) reduce EU dependence on protein imports; (ii) reduce the use of synthetic nitrogen fertilizer and subsequently decrease oil consumption and greenhouse gas emissions; (iii) diversify crop rotations for improved soil fertility and structure, reduced pesticide use, and greater biodiversity (Nemecek et al., 2006). At the farmer level, grain legume crops could play a key role in economically sustainable crop rotations thanks to their positive effect on the following crop and low input costs. However, in order to guarantee a durable introduction of legumes in crop rotations, significant productivity progress has to be made and stable and high-yielding varieties are needed. The PeaMUST project thus focuses on improving the competitiveness of pea, the major legume crop cultivated in Europe, by improving pea yield regularity in the context of climate change and pesticide reduction. 
Different biotic and abiotic stresses are responsible for yield instability, with varying impacts depending on the sowing time of pea varieties (winter or spring type). A major disease, Aphanomyces euteiches root rot, generates significant yield losses in peas and no method of control (genetic or chemical) is available at present (Carrouée and Moussart, 2011). In winter peas, early sowings allow increasing yield potential and limiting the effect of late-stage stresses but the genetics of frost tolerance is complex and a fungal pathogen, Mycosphaerella pinodes, causes aschochyta blight aerial damages (Tivoli, 2009) that can have devastating effects on yield. In both spring and winter peas, drought and heat during flowering and seed filling occur more frequently since 1998 and have significant impacts on seed production (Larmure et al., 2005; Bénézit et al., 2017). New risks linked with regulation change and the ban of many pesticides (Ecophyto2018 ${ }^{1}$ ) will rapidly emerge, especially herbivory insect attacks (aphids, seed and leaf weevils). Until now, genetic approaches to improve stress responses have been hampered by the highly multi-factorial nature of these traits. Recent advances in high-throughput sequencing, genotyping and phenotyping are important to achieve multiple stress tolerance.

Three complementary strategies have been implemented in the PeaMUST research project ${ }^{2}$ to enable efficient and rapid exploitation of useful genetic diversity. These strategies are based on:

- genome-wide characterisation of genetic diversity in different winter and spring type pea panels;

- comparative genomics for characterizing resistance and/or tolerance QTL;

- germplasm screening for identifying plant architecture ideotypes for multiple stress tolerance.

These different strategies will contribute to the ideotype design of future pea cultivars.

\section{Deducing targeted ideotypes from best candidates identified by genomic selection}

Breeding new varieties especially in the context of climate change needs to be efficient and fast. Therefore, adequate methods are necessary. Genomic selection (GS) has arisen as a promising breeding approach during the last decade (Bernardo and Yu, 2007; Lorenzana and Bernardo, 2009; Heffner et al., 2011). First results on genomic prediction in pea (Burstin et al., 2015; Tayeh et al., 2015) were encouraging and promoted this approach. The main advantages of GS over phenotype-based selection in breeding are that it enhances genetic gains by shortening the breeding cycle and/or enhancing testing efficiency in field evaluations. GS combines phenotypic data for a target trait in a training population with molecular data to obtain a prediction model and estimate the genomic breeding values of individuals in a testing population that have been genotyped but not phenotyped for this target trait. The unprecedented ease of access to high-throughput genotyping technologies is being paralleled by theoretical

\footnotetext{
${ }^{1}$ http://agriculture.gouv.fr/ministere/le-plan-ecophyto-2018.

${ }^{2}$ https://www.peamust-project.fr.
}

model and algorithm development to improve the accuracy of genomic prediction and account for the genetics of complex traits.

In PeaMUST, GS programs for the three different cultivated types of pea (spring pea, conventional winter pea, responsive to photoperiod winter pea) were launched with the ultimate goal to achieve yield stability. Yield stability is a highly multi-factorial trait and results from plant ability to adjust and respond to the environment. Phenotypes of the training populations were evaluated in multi-environmental field trials. A crop diagnosis modelling approach (Lecomte et al., 2010) was applied to identify the factors that limit plant productivity under each environment and to calculate the effect of these limiting factors on yield in the different genotypes. Contrary to phenotypic selection, running selection based on genomic-estimated breeding values from single traits allows identifying expected top lines without a priori on a favourable ideotype or plant characteristics other than the target trait. The GS of spring pea in PeaMUST has been run in its first generation using a selection index of eight traits comprising: yield, yield stability, thousand seed weight, protein content, flowering date, flowering duration, plant height, and lodging resistance. Evaluation of genomic selection versus phenotypic selection outputs in the field as well as in the under controlled conditions in a cutting-edge phenotyping platform (Jeudy et al., 2016) that allows both aerial and above-ground automated phenotyping will permit the posterior comparison of selected plant phenotypes and provide useful information about the superior ideotypes from the GS blind process.

\section{Pyramiding multiple resistance genes}

Breeding for pest and disease resistance has gradually evolved from an objective of monogenic per se resistance to an objective of global multigenic resistance, supposed to lead to a more durable resistance. Due to the partial effect of most resistance genes identified, to the need for resistance durability, and to the need for multiple stress resistance, a combination of genes and/or QTL is targeted to improve the level and durability of resistances. The ideotype in this case consists in cumulating different resistance alleles at different loci/genes controlled by different mechanisms of resistance.

In pea, a number of QTL of resistance to major stresses were consistently mapped over several environments and populations (Prioul et al., 2004; Pilet-Nayel et al., 2005; Lejeune-Hénaut et al., 2008). Seven highly consistent QTL responsible for partial resistance to A. euteiches were identified in recombinant inbred line (RIL) populations derived from crosses involving the best sources of resistance among the rare resistant accessions available in Pisum natural diversity (Hamon et al., 2013). Three consistent QTL of frost resistance have been identified (Lejeune-Hénaut et al., 2008) and 6 QTL controlling partial resistance to $M$. pinodes, among which 3 co-localized with frost tolerance QTL, were detected (Prioul et al., 2004). Building near-isogenic lines (NILs) harbouring different combinations of the main QTL for resistance to $A$. euteiches and frost $/ M$. pinodes allowed the identification of the best combinations for managing these stresses. 
The hypothesis underlying pyramiding is that different loci/genes control different mechanisms of resistance and their synergistic action may be more efficient in reducing the pathogen impact in time. It is thus of importance to identify the molecular determinants underlying identified QTL. Towards this aim, PeaMUST can benefit from translational genomics in legumes. Closely related species usually display high degree of conserved synteny (homologous genes located on syntenic blocks) and colinearity (conserved gene order within syntenic blocks). The syntenic relationships among pea, $M$. truncatula, L. japonicus and soybean (Tayeh et al., 2015) validated the translational genomics strategy in legumes. The identification of legume resistance genes provides relevant candidates to identify mapped QTL. Translational genomics can also open new perspectives for exploring unseen ideotypes in pea. For example, the exploration of natural variation for insect tolerance in faba bean identified two types of partial resistance/ avoidance, and one germplasm accession showing low damages (e.g. low attractivity towards insect) and defense, and another accession showing high levels of larvae mortality in the seed. The ideotype in this case is to cumulate these two types of resistance. In PeaMUST, the genetic and molecular basis of these traits are searched with the objective to transfer this knowledge to pea.

\section{Challenging architecture and biological regulations towards multi-stress tolerance}

Crop improvement in pea owes several outstanding success stories to the manipulation of aerial architecture controlling genes, such as the use of afila (af) and dwarf Mendel's le-1 mutations (Hofer and Ellis, 1998; Reid and Ross, 2011). Shoot architecture is a key component for multiple-stress tolerance. It determines canopy structure and therefore impacts lodging and epidemiology of aerial diseases (Le May et al., 2009). Root architecture has also been reported to be correlated with disease management, tolerance to abiotic stresses including drought and/or water and nutrient uptake. As most other legumes, pea does not need nitrogen fertilizer to accomplish its growth cycle. The presence of $\mathrm{N}_{2}$ fixing bacteria in the nodules, i.e. specific plant organs that develop on the roots, allows the reduction of atmospheric $\mathrm{N}_{2}$ into organic nitrogen that is then exported to the host plant. Root architecture is associated with differences in the number, size and distribution pattern of nodules and shapes interactions with rhizosphere microbial communities (Laguerre et al., 2007). Rhizobia and endomycorrhiza synthesize lipo-chito-oligosacharide (LCO) symbiotic signals (Nod factors and Myc-LCOs) that interact with plant growth and development (Maillet et al., 2011). In addition to plant genetics, LCOs and microbial inoculants could serve as tools to root architecture manipulation and improve plant performance through better resource uptake and protection against various stresses (Jeffries et al., 2003; Bourion et al., 2010; Currie et al., 2011). In PeaMUST, both forward and reverse screenings of mutant and genetic resources have identified interesting phenotypes in respect to plant architecture and development.

Leaf form, plant height, plant ramification modifications could improve lodging resistance and pathogen epidemics. During the PeaMUST project, a series of already known

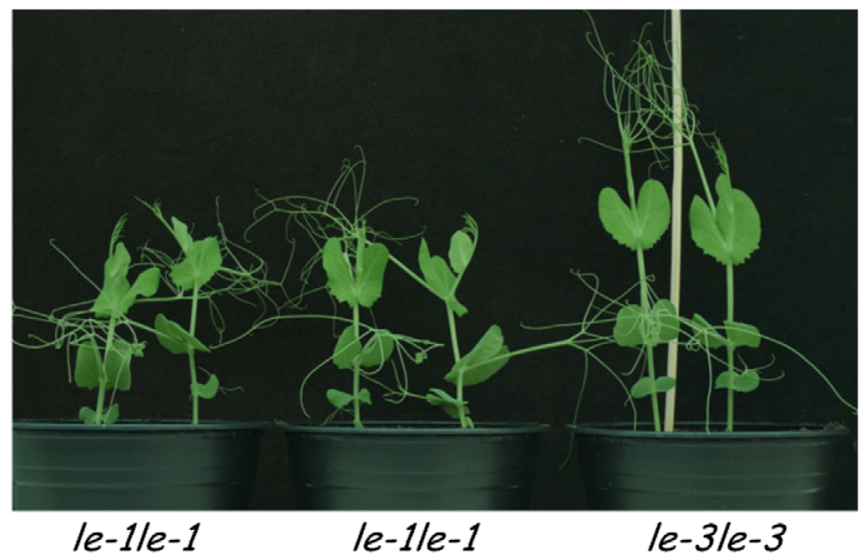

Fig. 1. Two different alleles of le are assessed in PeaMUST.

mutations/alleles of potential agronomical interest were backcrossed in 3 different agronomical genetic backgrounds (one spring line, one conventional winter pea, one responsive to photoperiod winter pea) for evaluation in field conditions. For example, the dwarfing Mendel's le-1 mutation, affecting gibberellin biosynthesis, seems to be the only dwarf gene/allele that has been used by pea breeders; another allele, le-3, described as less severe than $l e-1$ (Ross and Reid, 1991) was used in the project (Fig. 1). By slightly increasing internode elongation compared to $l e-1$ this allele could reduce aschochyta blight aerial damages. Its effect on yield and lodging resistance is also assessed since $l e-1$ add a slightly depressing effect on yield (Burstin et al., 2007) while having a highly beneficial effect on lodging. Novel mutations were also obtained by TILLING in genes of interest. To diversify the ways to get dwarf phenotypes, we screened for a pea semidominant gibberellin-response mutation. These types of mutations are of considerable agricultural significance as they are the genetic basis of the high yielding, semi-dwarf wheat (Rht1) and rice (sd1) varieties of the "green revolution" (Gale and Youssefian, 1985). Among the SQUAMOSA-PROMOTER BINDING PROTEIN-LIKE (SPL) family of transcription factors, those involved in the miR156/SPL module play important roles in regulating plant fitness, biomass, and yield (Wang and Wang, 2015). Mutations were searched for in 3 SPL homologues to investigate their potential agronomical interest. Another example of mutations tested in the PeaMUST project is alleles in the $\mathrm{Hr}$ gene conferring High Response to photoperiod, and increased basal branching. Different alleles trigger response to different daylength. An allele found in a germplasm line and novel alleles found in mutants screened in the novel TILLING population developed in PeaMUST using a winter pea line in the $\mathrm{Hr}$ gene ( $E L F 3$ in Arabidopsis) are being tested to diversify the response to photoperiod in pea.

Pea is also well-known for the numerous mutations controlling its compound leaf morphology. Pea has determinate pinnate compound leaves. A mature adult leaf consists of basal stipules, proximal leaflet pairs, distal tendril pairs, and a terminal tendril (Hofer and Ellis, 1998). The recessive afila mutation ( $a f$ ) was described by Kujala in 1953 (cited by Hofer and Ellis, 1998). Solov'eva (1958) and Goldenberg (1965) have later reported similar phenotypes in spontaneous mutations from the cultivars Svoboda and Cuarentona, 


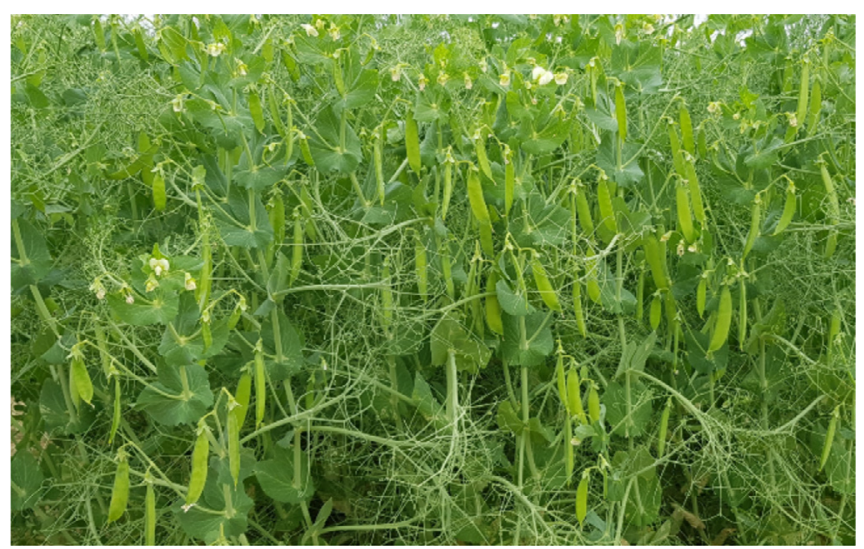

Fig. 2. The afila mutation has been introgressed in all field pea modern cultivars.

respectively. The af mutation leads to the conversion of leaflet primordia into lateral rachis primordia which in turn initiate second-order primordia (Cote et al., 1992). Tendril-bearing branched rachis are thus produced in place of proximal leaflets with branched tendrils in the proximal domain and simple tendrils in the distal and terminal domains. af has largely been used in P. sativum breeding programs and most of the current cultivars bear this mutation (Fig. 2). The introgression of af brings several benefits including: improved standing ability, improved light interception and canopy aeration, increased pathogen and pest resistance, better response to dry climate, better uniformity of ripening, easier drying and mechanical harvest, and in some backgrounds even higher grain yields (Snoad, 1974). No indication for significant decrease of photosynthetic activity associated with the afila allele has been reported but Burstin et al. (2007) and Bourion et al. (2010) found it possibly associated with unfavorable root, nodule and nitrogen nutrition traits. A mutation called $t t l$ leading to partial replacement of tendrils into leaflets is tested in PeaMUST to compare yield performance in comparison to the af and $A f$ types.

Root architecture diversity was also reported to be associated with tolerance to root disease avoidance. A few studies have shown the influence of root system architecture (RSA) traits on disease severity due to soil-borne pathogens. A large number of lateral roots, high root diameter or root dry weight were shown to be correlated with Fusarium root rot resistance in common bean (Román-Avilés et al., 2004) and pea (Kraft and Boge, 2001). In PeaMUST, experiments done on a collection of 266 pea lines or a subset of this collection, in field and controlled conditions, indicated that RSA is associated with tolerance to root disease induced by $A$. euteiches. Pea lines with good levels of resistance to $A$. euteiches and bushy root system (larger number of roots and longer roots) were identified and could be interesting for breeders to improve resistance to $A$. euteiches in pea varieties (Desgroux, 2016). Furthermore, a genome wide association study identified specific genomic regions controlling RSA and common loci associated with resistance to A. euteiches. Among them, a significant SNP marker detected for both improved resistance to A. euteiches and greater root projected area represent a valuable tool for marker assisted selection (Desgroux et al., 2018).

\section{References}

Bénézit M, Biarnès V, Jeuffroy MH. 2017. Impact of climate and diseases on pea yields: what perspectives with climate change? OCL 24: D103.

Bernardo R, Yu J. 2007. Prospects for genomewide selection for quantitative traits in maize. Crop Sci 47(3): 1082-1090.

Bourion V, Rizvi SM, Fournier S, et al. 2010. Genetic dissection of nitrogen nutrition in pea through a QTL approach of root, nodule, and shoot variability. Theor Applied Genet 121(1): 71-86.

Burstin J, Marget P, Huart M, et al. 2007. Developmental genes have pleiotropic effects on plant morphology and source capacity, eventually impacting on seed protein content and productivity in pea. Plant Physiol 144(2): 768-781.

Burstin J, Salloignon P, Chabert-Martinello M, et al. 2015. Genetic diversity and trait genomic prediction in a pea diversity panel. BMC Genomics 16: 105.

Carrouée B, Moussart A. 2011 Aphanomyces : quand le froid protège le pois. Bull Semen 220: 22-24.

Cote R, Gerrath JM, Posluszny U, Grodzinski B. 1992. Comparative leaf development of conventional and semileafless peas (Pisum sativum). Can J Bot 70: 571-580.

Currie AF, Murray PJ, Gange AC. 2011. Is a specialist root-feeding insect affected by arbuscular mycorrhizal fungi? Appl Soil Ecol 47 (2): 77-83.

Desgroux A. 2016. Rôle de l'architecture racinaire dans le contrôle génétique de la diminution des symptômes de pourriture racinaire dus à Aphanomyces euteiches chez le pois (Pisum sativum). Doctoral dissertation, 342 p. available on: https://tel.archivesouvertes.fr/tel-01615191v2/document.

Desgroux A, Baudais VN, Aubert V, et al. 2018. Comparative genome-wide-association mapping identifies common loci controlling root system architecture and resistance to aphanomyces euteiches in pea. Front in Plant Sci 8: 2195.

Gale MD, Youssefian S. 1985. Dwarfing genes in wheat. In: Russel GE, ed. Progress in plant breeding. London, (UK): Butterworths, pp. $1-35$.

Goldenberg JB. 1965. afila, a new mutation in pea (Pisum sativum L.). Bol Genet 1: 27-28.

Hamon C, Coyne CJ, McGee RJ, et al. 2013. QTL meta-analysis provides a comprehensive view of loci controlling partial resistance to Aphanomyces euteiches in four sources of resistance in pea. BMC Plant Biol 13: 45.

Heffner E, Jannink JL, Sorrells ME. 2011. Genomic selection accuracy using multifamily prediction models in a wheat breeding program. The Plant Genome 4(1): 65-75.

Hofer JMI, Ellis THN. 1998. The genetic control of patterning in pea leaves. Trends Plant Sci 3(11): 439-444.

Jeffries P, Gianinazzi S, Perotto S, Turnau K, Barea JM. 2003. The contribution of arbuscular mycorrhizal fungi in sustainable maintenance of plant health and soil fertility. Biol Fertil Soils 37 (1): $1-16$.

Jeudy C, Adrian M, Baussard C, et al. 2016. RhizoTubes as a new tool for high throughput imaging of plant root development and architecture: test, comparison with pot grown plants and validation. Plant Methods 12: 31.

Kraft JM, Boge W. 2001. Root characteristics in pea in relation to compaction and Fusarium root rot. Plant Dis 85(9): 936-940.

Laguerre G, Depret G, Bourion V, Duc G. 2007. Rhizobium leguminosarum $b v$. viciae genotypes interact with pea plants in developmental responses of nodules, roots and shoots. New Phytol 176: 680-690. 
Larmure A, Salon C, Munier-Jolain NG. 2005. How does temperature affect $\mathrm{C}$ and $\mathrm{N}$ allocation to the seeds during the seed-filling period in pea? Effect on seed nitrogen concentration. Funct Plant Biol 32: 1009-1017.

Lecomte C, Prost L, Cerf M, Meynard JM. 2010. Basis for designing a tool to evaluate new cultivars. Agron Sustain Dev 30: $667-677$.

Lejeune-Hénaut I, Hanocq E, Béthencourt L, et al. 2008. The flowering locus $\mathrm{Hr}$ colocalizes with a major QTL affecting winter frost tolerance in Pisum sativum L. Theor Appl Genet 116: 11051116.

Le May C, Ney B, Lemarchand E, Schoeny A, Tivoli B. 2009. Effect of pea plant architecture on spatiotemporal epidemic development of Ascochyta blight (Mycosphaerella pinodes) in the field. Plant Pathol 58: 332-343.

Lorenzana R, Bernardo R. 2009. Accuracy of genotypic value predictions for marker-based selection in biparental plant populations. Theor Appl Genet 120(1): 151-161.

Maillet F, Poinsot V, André O, et al. 2011. Fungal lipochitooligosaccharide symbiotic signals in arbuscular mycorrhiza. Nature 469: 58-U1501.

Nemecek T, von Richthofen JS, Dubois G, Casta P, Charles R, Pahl H. 2008. Environmental impacts of introducing grain legumes into European crop rotations. Eur J Agron 28: 380-393.

Pilet-Nayel ML, Muehlbauer FJ, McGee RJ, Kraft JM, Baranger A, Coyne CJ. 2005. Consistent quantitative trait loci in pea for partial resistance to Aphanomyces euteiches isolates from the United States and France. Phytopathology 95: 1287-1293.

Prioul S, Frankewitz A, Deniot G, Morin G, Baranger A. 2004. Mapping of quantitative trait loci for partial resistance to Mycosphaerella pinodes in pea (Pisum sativum L.), at the seedling and adult plant stages. Theor Appl Genet 108: 1322-1334.

Reid JB, Ross JJ. 2011. Mendel's genes: Toward a full molecular characterization. Genetics 189(1): 3-10.

Román-Avilés B, Snapp SS, Kelly JD. 2004. Assessing root traits associated with root rot resistance in common bean. Field Crops Res 86(2): 147-156.

Ross JJ, Reid JB. 1991. Internode length in Pisum: le5839 is a less severe allele than Mendel's le. Pisum Genet 23: 29-34.

Snoad B. 1974. A preliminary assessment of 'leafless peas'. Euphytica 23: 257-265.

Solov'eva VK. 1958. New varieties of shelling peas. Agrobiologiya 5: 124-126.

Tayeh N, Klein A, Le Paslier MC, et al. 2015. Genomic prediction in pea: Effect of marker density and training population size and composition on prediction accuracy. Front Plant Sci 6: 941.

Tivoli B. 2009. Studies on ascochyta blight on pea in France: epidemiology and impact of the disease on yield and yield components. Grain Legum 52: 14-15.

Wang H, Wang H. 2015. The miR156/SPL Module, a regulatory hub and versatile toolbox, gears up crops for enhanced agronomic taits. Mol Plant 8(5): 677-688.

Cite this article as: Burstin J, Rameau C, Bourion V, Tayeh N. 2018. The PeaMUST project: defining ideotypes for the pea crop development. OCL 25(6): D604. 